\title{
Performance Appraisal of Bhimsagar Irrigation Scheme using Comparative Performance Indicators
}

\author{
Jitendra Rajput* and Mahesh Kothari \\ Department of Soil and Water Engineering CTAE, MPUAT, Udaipur, Rajasthan, India \\ *Corresponding author
}

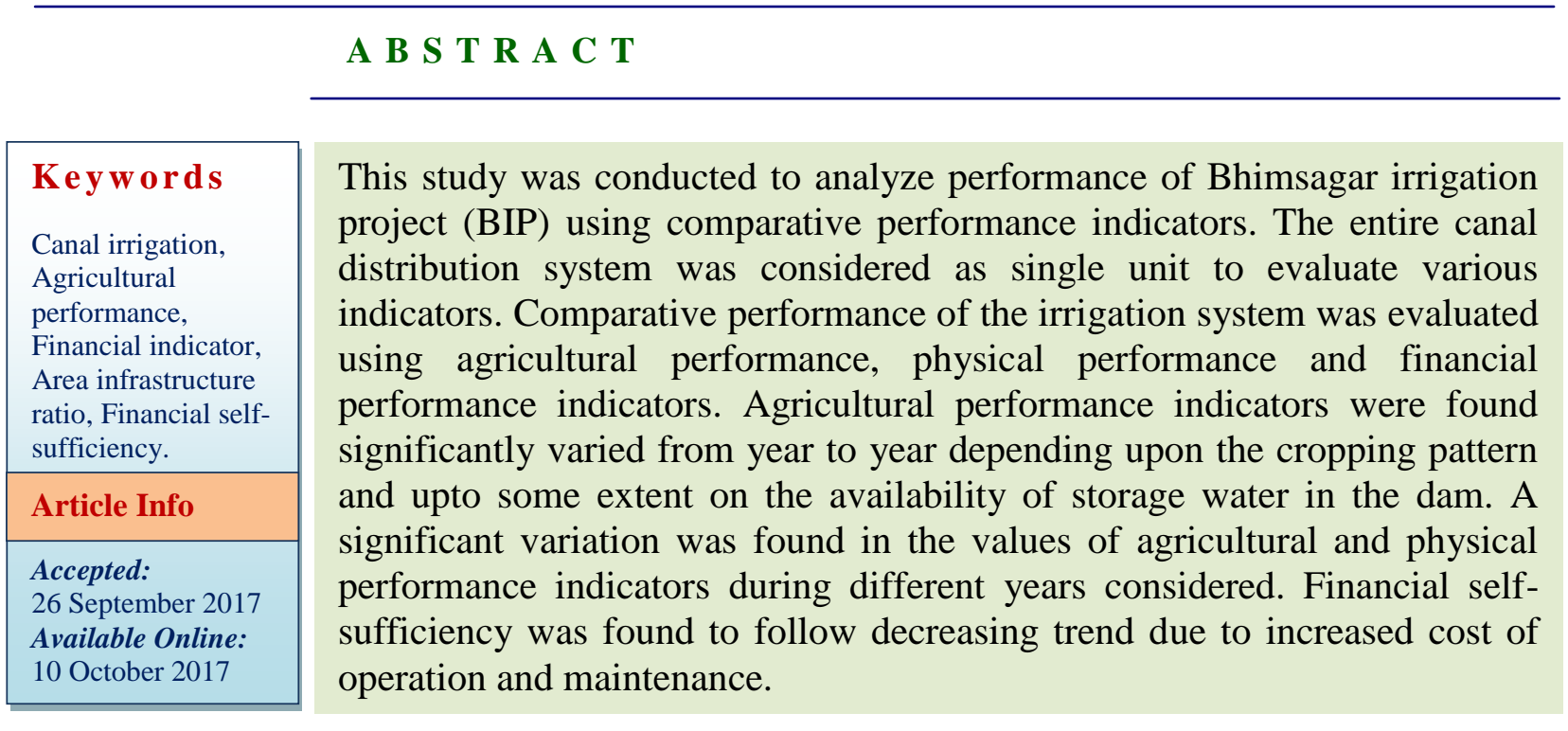

\section{Introduction}

Water is a critical agricultural resource which is becoming scarcer due to increasing demands and its efficient use in irrigation may combat the effects of hunger. Researcher Molden et al., (2007) reported that a fifth of the world's population lives in areas where water is physically scarce and around $25 \%$ live in economically water-scarce basins. Food and Agriculture Organization (FAO) predicted that food production must increase by $70 \%$ globally and that the developing countries must double production to match a $40 \%$ increase in world population by 2050 (Mukherji et al., 2009).
Rajasthan is the largest State of India covering nearly 10.4 per cent of total geographical area (329 Billion hectare) of the country out of which two third is under Desert and only one third is available for agriculture use but has only 1.04 percent of water resources (census, 2011). Agriculture in Rajasthan is primarily rainfed. Approximately 24.34 percent of the irrigated area is under canal irrigation where water delivery (canal opening) is not coinciding with critical crop growth stages. On the right side of the Aravallis and east and south eastern parts of the state are comparatively better placed and 
fertile. Chambal, Banas, Mahi and all other rivers and tributaries add prosperity to this region.

The canal water is one of the main sources of irrigation in arid and semiarid region. The irrigation scenario in India is characterized by poor irrigation system performance, increased demand for higher productivity and increasing soil salinity. A good irrigation management should provide higher economic output beside water saving and high yield (Pareira, 2003). Due to increasing cost in developing new water resources, the only option left is to enhance the current level of performance of irrigation systems.

Irrigation sector is the highest water consumer; therefore it is a sector where performance assessment is necessary to ensure optimum utilization of water. International Water Management Institute (IWMI) suggests using a minimum set of comparative indicators to assess hydrological, agronomic, economic, financial, and environmental performances of irrigation systems. The aim of applying comparative indicators is to evaluate outputs and impacts of irrigation management practices, interventions across different systems and system levels, as well as to compare various irrigation seasons and technologies with one another. And also, these indicators are small, not data intensive and are cost-effective (Kloezen and Garces-Restrepo, 1998).

Murray-Rust and Snellen (1993) described the framework of using performance indicators, and noted two approaches for the use of performance indicators in the field of irrigation: A) Attempts to develop indicators that allow the performance of one system to be compared to similar systems elsewhere. B) The use of indicators to compare actual results with what was planned. Sharma and Rao (1996) evaluated the Integrated Water
Management Scheme, which was in operation in the command area of the Paladugu major distributaries in the Nagarjuna Sagar Right Canal Command Area in Andhra Pradesh and results revealed that the scheme effectively led to a sustained increase in the irrigated area and irrigation intensity (by $>25 \%$ ) resulting in increased crop production.

Molden et al., (1998) compared performance of eighteen irrigation systems located in eleven different countries through various indicators and reported that results showed large differences in performance among the systems. Degirmenci et al., (2003) in their study used, six comparative indicators for the assessment of irrigation system performance were applied to 12 irrigation schemes, which were components of the Southeastern Anatolian Project, for the period 1997-2001. Sener et al., (2007) mentioned that water distribution is not tightly related to crop water demand. Physical performance, evaluated in terms of irrigation ratio and sustainability of irrigated land, were poor in Hayrabolu Irrigation Scheme of the Thrace district in Turkey

The major system deficiencies are low canal carrying capacity, over utilizations of water in Rabi irrigation, flooding irrigation practices, low yield per unit irrigated area, and low cost recovery in the Samrat Ashok Sagar irrigation project (Phadnis and Kulshrestha 2010). Sener and Albut (2011) applied five comparative indicators were applied on 10 irrigation systems in Thrace region and performance was evaluated.

Out of 10 irrigtaion schemes, irrigation schemes such as Suleoglu, Kuplu and Hayrabolu where there is inadequate water resources, it is better to plant vegetable and industrial crops which require small amount of water and have a higher economic value instead of planting field crops. 
Several Studies on irrigation system performance using comparative indicators have been conducted throughout the world by number of researchers. The aim of carrying out present study was to evaluate performance of Bhimsagar irrigation system using comparative performance indicators that will allow for comparative analysis of irrigation performance across irrigation system. These indicators reveal about the relative health of the irrigation system over the years.

\section{Materials and Methods}

\section{Description of Bhimsagar irrigation project}

The Bhimsagar irrigation project (BIP) is a medium irrigation scheme having Culturable command area (CCA) of 9986 ha. It is situated on the river Ujjar, a tributary of Kalisindh River near the village Mau-Borda of tehsil Khanpur in the district Jhalawar, Rajasthan. The scheme envisaged construction of storage dam of $76.6 \mathrm{M}$ Cubic meter capacity with surplus arrangements for 1924.40 Cumec, across river Ujjar and canal system for providing irrigation facilities to CCA of 9986 ha of land in Khanpur tehsil of district Jhalawar.

\section{Canal system}

The Canal system consists of one Left Main Canal (LMC) and one Right Main Canal. There are 19 minors off take from the two main canals among which 5 minors from the right main canal and 14 minors from the left main canal. Gross command area (GCA) of the Bhimsagar irrigation scheme is 10512 ha and irrigated cropped area (ICA) is 8903 ha. Culturable command area (CCA) under Both Main Canals is 9986 hectare in Rabi season (7278 ha from LMC and 2708 ha from RMC). The maximum depth of water table ranges between 20 to $25 \mathrm{~m}$ below the ground surface during summer. The catchment of river Ujjar is mostly hilly with patches of cultivation up to the point where the dam site is located. The area lower down is cultivated and flat.

\section{Standardized Gross Value of Production (SGVP)}

The Standardized Gross Value of Production (SGVP) makes it possible to compare the performance of systems, no matter where they are or what kind of crops are being grown. Output per unit of water used to grow oranges in Mexico can be compared with that of water used to grow apples in Nepal. The SGVP captures both local preferences-for example, specialized crops that may have a low international price, but a high local value-and the value of non-traded crops.

$\mathrm{SGVP}=\left(\sum_{\text {crops }} A_{i} Y_{i} \frac{P_{i}}{P_{b}}\right) P_{\text {district }}$

Where,

A $i$ is the area cropped with crop $i$ (ha), $\mathrm{Y} i$ is the yield of crop $i(\mathrm{Kg} / \mathrm{ha})$, $\mathrm{P} i$ is the local price $i$ (Rs. $/ \mathrm{Kg}$ ),

$\mathrm{Pb}$ is the local price of the base crop (the predominant locally-grown, internationallytraded crop) (Rs. $/ \mathrm{Kg}$ ) and $\mathrm{P}_{\mathrm{d}}$ district is the value of the base crop traded at district prices.

\section{Agricultural performance indicators}

The first four indicators relate the monetary value of the system's final output, agricultural production, to the inputs of land and water. By standardizing the gross value of agricultural production and relating it to inputs common to all systems (land and water), these indicators make it possible to compare the performance of radically different systems. These indicators were calculated as follows (Molden et al., 1998): 
Output per unit cropped area $=$ SGVP/ Irrigated cropped area.

Output per unit command $=\mathrm{SGVP} /$ Command Area.

Output per unit irrigation supply $=\mathrm{SGVP} /$ Diverted irrigation supply.

Output per unit water consumed $=\mathrm{SGVP} /$ Volume of water consumed by ET.

\section{Physical Performance}

Physical indicators are related with the changing or losing irrigated land in the command area by different reasons.

\section{Irrigation Ratio}

The intensity with which the irrigated area is cropped traditionally is a function of the number of crops per year grown on an irrigated area. For cropping patterns of various crops with widely different lengths of growing period, and for orchards, however, this cropping intensity is not well defined. To quantify the 'occupancy' of the irrigable area by a crop it is recommended to use the ratio.

Irrigation ratio $=$ Land Irrigable $/$ Land Irrigated.

\section{Sustainability of irrigated area}

It refers to the portion of the actually irrigated area (ha) in given irrigation season. Irrigable area (ha) is the potential scheme command area (Vermillion, 2000).

Sustainability of Irrigated Area $=$ Area Irrigated /Area Irrigated Initially.

\section{Area infrastructure ratio}

Area infrastructure ratio is determined by dividing current total irrigated area to the total length of canal and laterals on the system.
Area Infrastructure Ratio $=$ Irrigated Area/Length of Canal and Laterals

\section{Financial performance}

Two financial indicators were used to evaluate performance of the system which is given below:

\section{Gross return on investment (\%)}

It is the ratio of standard gross value of production (SGVP) to the cost of irrigation infrastructure.

Gross return on investment =

$\frac{\text { SGVP }}{\text { Cost of Irrigation Infrastr }}$

\section{Financial self-sufficiency}

It is the ratio of revenue from irrigation to the total operation and maintenance expenditure

Financial Self-Sufficiency =

\section{Revenue from Irri}

Total O\&M Expend

Cost of irrigation infrastructure considers the cost of the irrigation water delivery system referenced to the same year as the SGVP, Revenue from irrigation, is the revenue generated, either from fees, or other locally generated income, and Total O\&M expenditures are the amount expended locally through O\&M plus outside subsidies from the government.

The financial self-sufficiency less than 100 per cent indicates, operation and maintenance expenditure were more than total revenue collected from irrigation services. 


\section{Results and Discussion}

\section{Comparative indicators}

Various comparative indicators have been used for evaluating performance Bhimsagar irrigation project. Evaluation was done by comparing performance of canal on agricultural aspects like output per unit land cropped, command area, irrigation diverted and water consumed. The Canal system was also assessed based on its physical performance by measuring Irrigation Ratio, Sustainability, and Area/Infrastructure Ratio. Financial Indicators were also calculated to evaluate performance of Bhimsagar Irrigation Project.

\section{Standardized gross value of production}

The Standard Gross Value of Production ranges between Rs. 71.30 Million to Rs. 342.10 Million are shown in Table 2.

\section{Agricultural performance}

Among the agricultural performance indicators, four comparative indicators were used to assess the impacts of multiple factors like cropping pattern, intensity, irrigation supply etc. on irrigation system over time. These are - Output Per unit Land Cropped (OPLC), Output Per unit of Command Area (OPCA), Output Per unit of Irrigation Supply (OPIS), and Output Per unit of Water Consumed (OPWC) respectively.

The Standard Gross Value of Production ranges between Rs. 71.30 Million to Rs. 342.10 Million are shown in Table 3. Values of Output Per unit Land Cropped, Output Per unit Command Area, Output Per unit Irrigation Supply and Output Per unit Water Consumed were calculated from 2009-14 are given in Table 3. Output per unit Land Cropped in Bhimsagar command area was found highest in the year 2013-14 with
71367.70 Rs/ha and the lowest in 2009-10 with $30407.70 \mathrm{Rs} / \mathrm{ha}$. Such variations in consecutive years show fluctuations in cropping pattern of command area.

Output Per unit Command Area in Bhimsagar command area was obtained maximum in 2013-14 with $34354.40 \mathrm{Rs} / \mathrm{ha}$ and minimum in 2009-10 with $7143.60 \mathrm{Rs} / \mathrm{ha}$. This implies less output as compared to command area that shows a lesser amount of land has been cropped than available.

Output Per unit Irrigation Supply was measured highest in 2010-11 with $9.56 \mathrm{Rs} / \mathrm{m}^{3}$ and the lowest in 2011-12 with $3.33 \mathrm{Rs} / \mathrm{m}^{3}$. It shows more water had been supplied in 201112 with low yield, it is due to improper distribution of water to fields and adoption of inadequate and inefficient agricultural practiced used by farmers. Output Per unit Water Consumed (OPWC) found good in 2013-14 with $23.80 \mathrm{Rs} / \mathrm{m}^{3}$ and poor in 201112 with $1.75 \mathrm{Rs} / \mathrm{m}^{3}$. This parameter assessed low crop water consumption and more output in year 2012-13. It is due to use of good crop variety for cultivation.

Average values of OPLC and OPCA were calculated as $53072.60 \mathrm{Rs} / \mathrm{ha}$ and 19168.64 $\mathrm{Rs} / \mathrm{ha}$ respectively presented in fig 2 whereas Average values of OPIS and OPWC was found $6.06 \mathrm{Rs} / \mathrm{m}^{3}$ and $13.80 \mathrm{Rs} / \mathrm{m}^{3}$ respectively and shown in fig 3 .

Different annual values were obtained for Bhimsagar command due to the changes in cropping pattern, change in price of base crop in world market, change in values of local price of crops grown in command area.

\section{Physical performance}

The physical performance of Bhimsagar irrigation system is evaluated by computing Irrigation Ratio, Sustainability of Irrigated Area and Area Infrastructure Ratio. 
Table.1 Climatologically parameters of project area (2001-2012)

\begin{tabular}{|c|c|c|c|c|c|c|c|c|}
\hline \multirow[t]{2}{*}{ Month } & \multicolumn{2}{|c|}{ Temperature ${ }^{0} \mathrm{C}$} & \multicolumn{2}{|c|}{ R.H. \% } & \multirow{2}{*}{$\begin{array}{l}\text { Wind Velocity } \\
\text { (Km/hrs) }\end{array}$} & \multirow{2}{*}{$\begin{array}{l}\text { Rainfall } \\
(\mathrm{mm})\end{array}$} & \multirow{2}{*}{$\begin{array}{l}\text { Bright } \\
\text { sunshine, (hrs.) }\end{array}$} & \multirow{2}{*}{$\begin{array}{l}\text { Evaporation } \\
\text { (mm/day) }\end{array}$} \\
\hline & Max. & Min. & $7: 27$ & $14: 27$ & & & & \\
\hline Jan & 22.8 & 6.4 & 86.7 & 42.2 & 3.5 & 0.0 & 7.6 & 2.3 \\
\hline Feb & 26.0 & 9.8 & 80.5 & 35.4 & 3.4 & 0.0 & 8.7 & 3.2 \\
\hline Mar & 33.5 & 14.6 & 62.6 & 20.2 & 3.8 & 0.0 & 9.5 & 5.3 \\
\hline Apr & 39.0 & 21.4 & 43.0 & 13.5 & 4.0 & 0.0 & 9.9 & 8.2 \\
\hline May & 42.2 & 27.1 & 41.5 & 17.1 & 5.1 & 0.0 & 10.0 & 10.4 \\
\hline Jun & 39.3 & 28.1 & 59.3 & 36.2 & 5.6 & 104.5 & 8.4 & 8.7 \\
\hline Jul & 34.3 & 26.3 & 81.4 & 63.0 & 4.1 & 284.8 & 5.2 & 5.2 \\
\hline Aug & 31.7 & 25.2 & 87.5 & 69.9 & 3.2 & 270.4 & 4.7 & 4.1 \\
\hline Sep & 32.8 & 23.8 & 84.0 & 56.3 & 2.6 & 164.3 & 8.0 & 4.3 \\
\hline Oct & 34.6 & 17.9 & 80.4 & 295 & 2.3 & 2.7 & 9.3 & 4.2 \\
\hline Nov & 30.2 & 12.2 & 84.6 & 31.5 & 2.5 & 0.0 & 8.2 & 3.3 \\
\hline Dec & 25.4 & 8.3 & 88.6 & 37.9 & 5.1 & 0.0 & 7.3 & 2.4 \\
\hline
\end{tabular}

Table.2 Standard gross value of production

$\begin{array}{llll}\text { Years } & \text { Irrigated Cropped Area (ha) } & \text { ET (M m3) } & \text { SGVP }\left(\mathbf{1 0}^{\mathbf{6}} \text { Rs. }\right) \\ \mathbf{2 0 0 9 - 1 0} & 2346 & 7.80 & 71.30 \\ \mathbf{2 0 1 0 - 1 1} & 1680 & 5.29 & 77.70 \\ \mathbf{2 0 1 1 - 1 2} & 3700 & 11.73 & 206.00 \\ \mathbf{2 0 1 2 - 1 3} & 4200 & 13.35 & 259.00 \\ \mathbf{2 0 1 3 - 1 4} & 4793 & 14.36 & 342.10\end{array}$

Table.3 Comparative indicators from year 2009-10 to 2013-14

\begin{tabular}{|c|c|c|c|c|}
\hline Years & $\begin{array}{c}\text { Output Per unit of } \\
\text { Land Cropped } \\
(\mathbf{R s} / \mathbf{h a})\end{array}$ & $\begin{array}{c}\text { Output Per unit of } \\
\text { Command Area } \\
(\mathbf{R s} / \mathbf{h a})\end{array}$ & $\begin{array}{c}\text { Output Per unit of } \\
\text { Irrigation Supply } \\
\left(\mathbf{R s} / \mathbf{m}^{\mathbf{3}}\right)\end{array}$ & $\begin{array}{c}\text { Output Per unit of } \\
\text { Water Consumed } \\
\left(\mathbf{R s} / \mathbf{m}^{\mathbf{3}}\right)\end{array}$ \\
\hline $\mathbf{2 0 0 9 - 1 0}$ & 30407.70 & 7143.60 & 5.47 & 9.15 \\
\hline $\mathbf{2 0 1 0 - 1 1}$ & 46245.40 & 7780.10 & 9.56 & 14.68 \\
\hline $\mathbf{2 0 1 1 - 1 2}$ & 55675.60 & 20628.80 & 3.33 & 1.75 \\
\hline $\mathbf{2 0 1 2 - 1 3}$ & 61666.60 & 25936.30 & 4.69 & 19.40 \\
\hline $\mathbf{2 0 1 3 - 1 4}$ & 71367.70 & 34354.40 & 7.25 & 23.80 \\
\hline Average & 53072.60 & 19168.64 & 6.06 & 13.80 \\
\hline
\end{tabular}

Table.4 Irrigation ratio for Bhimsagar irrigation project

$\begin{array}{cccc}\text { Years } & \text { Irrigated Land (ha) } & \text { Irrigable Land (ha) } & \text { Irrigation Ratio (per cent) } \\ 2004-05 & 2500 & 8903 & 28 \\ 2005-06 & 3560 & 8903 & 40 \\ 2006-07 & 4560 & 8903 & 51 \\ 2007-08 & 3050 & 8903 & 34 \\ 2008-09 & 3780 & 8903 & 42 \\ 2009-10 & 3268 & 8903 & 37 \\ 2010-11 & 4200 & 8903 & 47 \\ 2011-12 & 6870 & 8903 & 77 \\ 2012-13 & 7990 & 8903 & 90 \\ 2013-14 & 8680 & 8903 & 97 \\ & \text { Average } & & \mathbf{5 4}\end{array}$


Table.5 Sustainability of irrigated area

$\begin{array}{cccc}\text { Years } & \text { Irrigated Area (ha) } & \text { Initial Irrigated Area (ha) } & \text { Sustainability of Irrigated Area (per cent) } \\ 2004-05 & 2500 & 5640 & 44.33 \\ 2005-06 & 3560 & 5640 & 63.12 \\ 2006-07 & 4560 & 5640 & 80.85 \\ 2007-08 & 3050 & 5640 & 54.08 \\ 2008-09 & 3780 & 5640 & 67.02 \\ 2009-10 & 3268 & 5640 & 57.94 \\ 2010-11 & 4200 & 5640 & 74.47 \\ 2011-12 & 6870 & 5640 & 121.81 \\ 2012-13 & 7990 & 5640 & 141.67 \\ 2013-14 & 8680 & 5640 & 153.90 \\ & & & \mathbf{8 5 . 9 2}\end{array}$

Table.6 Area Infrastructure Ratio (AIR)

$\begin{array}{llll}\text { Years } & \text { Irrigated Land (ha), Total area } & \text { Total Length of Canals }(\mathbf{K m}) & \text { Area Infrastrucure Ratio (ha/Km) } \\ 2004-05 & 2500 & 52 & 48.08 \\ 2005-06 & 3560 & 52 & 68.46 \\ 2006-07 & 4560 & 52 & 87.69 \\ 2007-08 & 3050 & 52 & 58.65 \\ 2008-09 & 3780 & 52 & 72.69 \\ 2009-10 & 3268 & 52 & 62.85 \\ 2010-11 & 4200 & 52 & 80.77 \\ 2011-12 & 6870 & 52 & 132.12 \\ 2012-13 & 7990 & 52 & 153.65 \\ 2013-14 & 8680 & 52 & 166.92 \\ \text { Average } & & & \mathbf{9 3 . 1 9}\end{array}$

Table.7 Gross return on investment

$\begin{array}{llll}\text { Years } & \text { Cost of Irrigation Infrastructure }\left(\text { Rs. } \mathbf{~ 1 0}^{\mathbf{6}}\right) & \text { SGVP }(\text { Rs. 10 } & \\ 2009-10 & 659.22 & 71.3 & \text { Gross Return on Investment (\%) } \\ 2010-11 & 738.32 & 77.7 & 10.8 \\ 2011-12 & 826.92 & 206.0 & 10.5 \\ 2012-13 & 926.16 & 259.0 & 24.9 \\ 2013-14 & 1037.29 & 342.1 & 28.0 \\ & & & 33.0\end{array}$

Table.8 Financial Self-Sufficiency for Bhimagar irrigation project

$\begin{array}{cccc}\text { Year } & \begin{array}{c}\text { Operation and Maintenance } \\ \text { Expenditure (Rs. in Lakhs) }\end{array} & \begin{array}{c}\text { Revenue from Irrigation } \\ \text { (Rs. In Lakhs.) }\end{array} & \begin{array}{c}\text { Financial Self-Sufficiency } \\ \text { (\%) }\end{array} \\ 2006-07 & 22.86 & 40 & 174 \\ 2007-08 & 27.53 & 40 & 145 \\ 2008-09 & 39.8 & 40 & 100 \\ 2009-10 & 47.12 & 40 & 84 \\ 2010-11 & 48.35 & 40 & 82 \\ 2011-12 & 47.12 & 40 & 84 \\ 2012-13 & 67.80 & 40 & 59 \\ 2013-14 & 74.00 & 40 & 54 \\ & \text { Average } & & \mathbf{9 7}\end{array}$




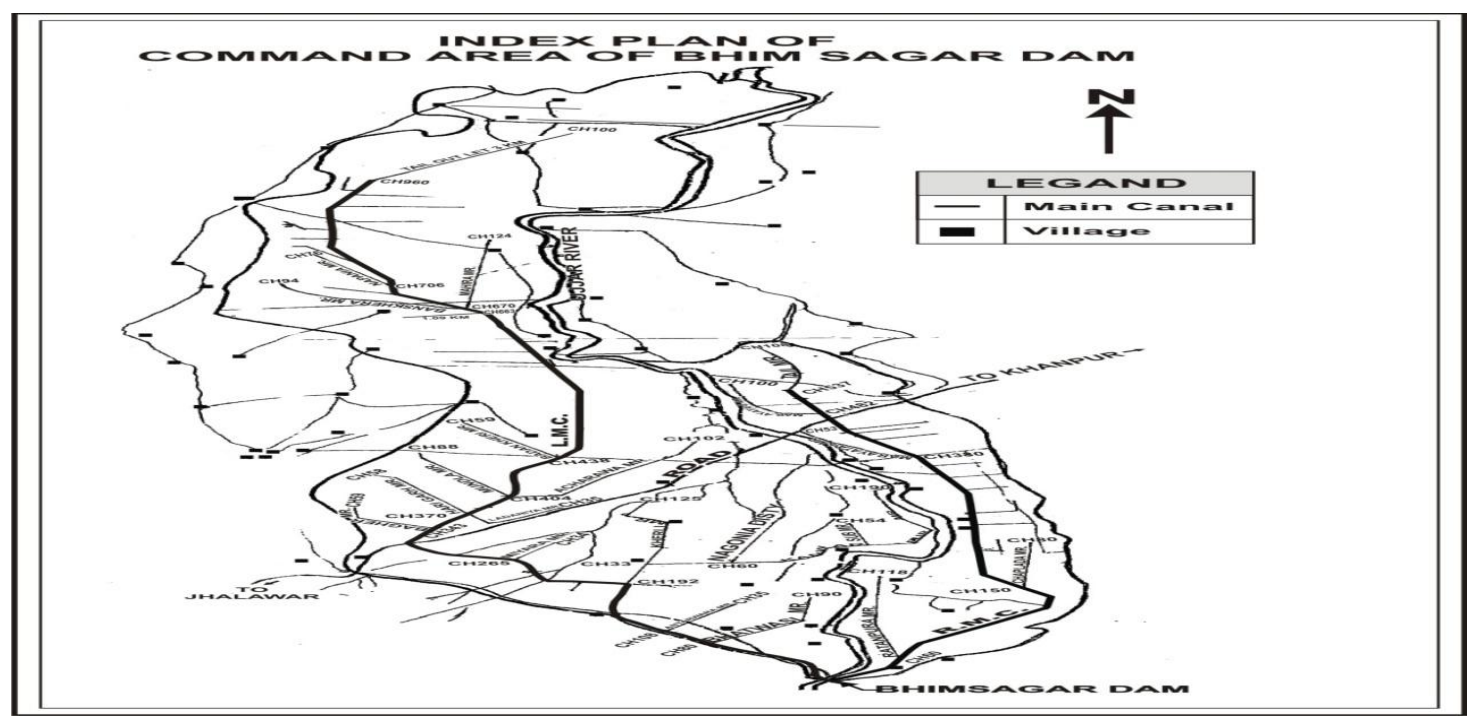

Fig.2 Comparisons between average values of output per unit of land cropped and output per unit of command area

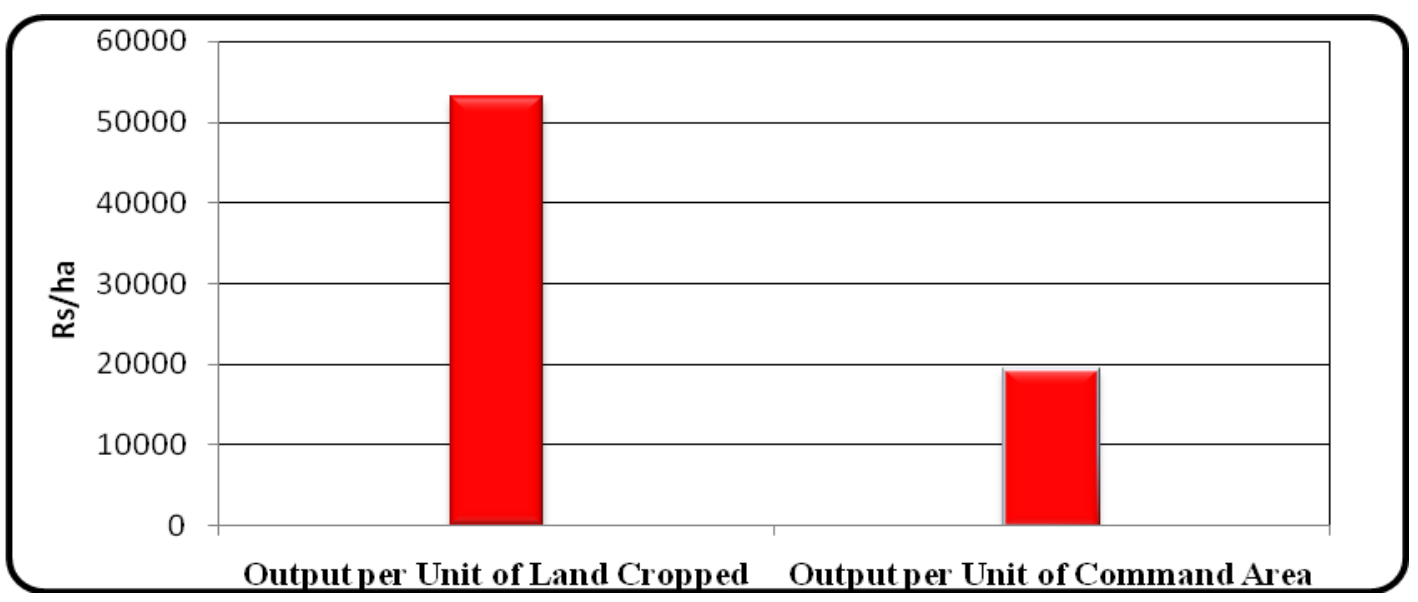

Fig.3 Comparisons between average values of output per unit of irrigation supply and output per unit of water consumed

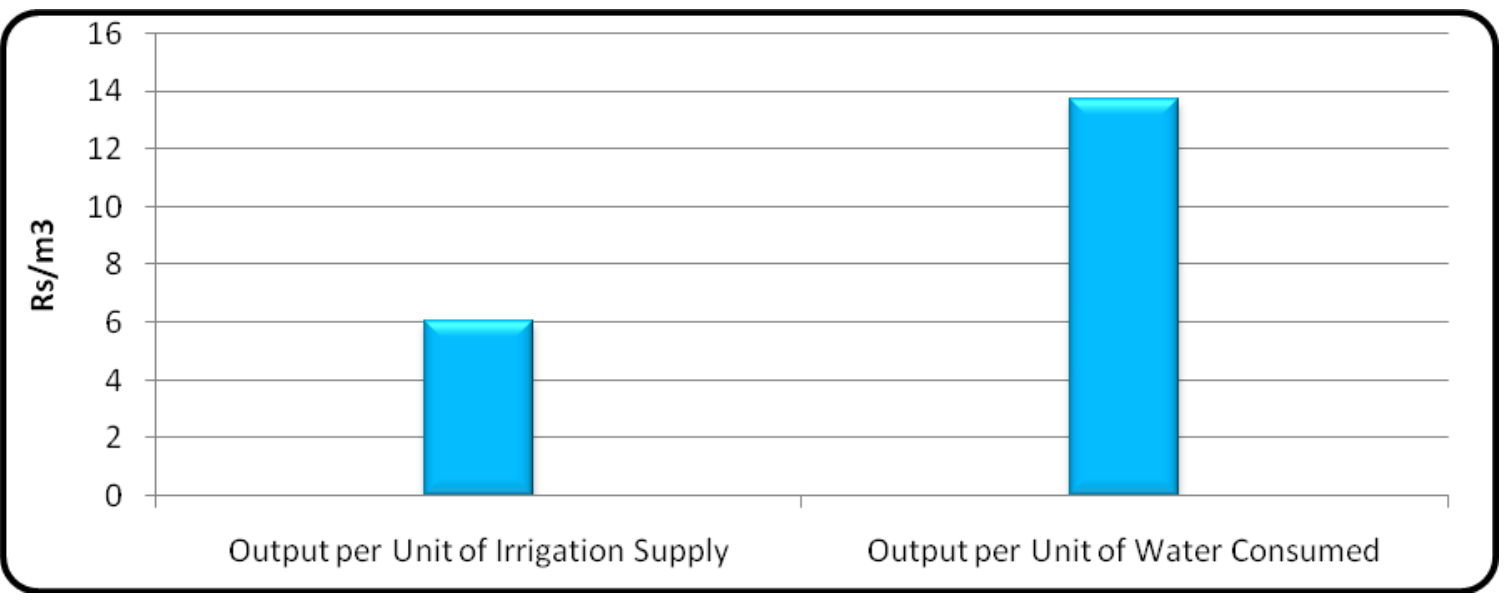




\section{Irrigation Ratio (IR)}

Irrigation ratio for Bhimsagar irrigation project is given in table 4 and explains year wise irrigation ratio. The average value of irrigation ratio for the period 2004-05 to 2013-14 was found to be 54 per cent. The maximum value of IR was 97 per cent and obtained in year 2013-14 and minimum IR is 28 per cent in the year 2004-05.

\section{Sustainability of Irrigated Area (SIA)}

The sustainability is explained as ratio of current irrigated area to the initial irrigated area. It determines continuity of the system in increasing or maintaining the same initial irrigated area. The value equal to 100 per cent shows that system is sustainable. Minimum area was irrigated in 2004-05 giving value of 44.33 per cent showing no sustainability during this year. An average SIA of 85.92 per cent was found for period in between 2004-05 to 2013-2014. The system was not suitable till year 2010-11 and onwards has Sustainability of Irrigated Area (SIA) as it is more than 100 per cent. The sustainability is explained in Table 5.

\section{Area Infrastructure Ratio (AIR)}

Area infrastructure ratio is determined by dividing current total irrigated area to the total length of canal and laterals on the system. An AIR value decides how well cost of infrastructure has been maintained since its installation. For evaluating the performance of Bhimsagar Irrigation Project, an ideal indicator value of Area Infrastructure Ratio (AIR) of initially irrigated area (5640 ha) and total length of canal $(52 \mathrm{Km})$ was calculated as $108.46 \mathrm{ha} / \mathrm{Km}$. Year wise total irrigated area and total length of the canal is tabulated in Table 6.. The calculated value of AIR for all the years except 2011-12 to 2013-14 were found lower than ideal indicator value showing no sustainability with regard to infrastructure expenses. The value of AIR was between 48.08 to166.92 ha/Km, with an average of $93.19 \mathrm{ha} / \mathrm{Km}$.

\section{Financial indicators}

Performance was evaluated by employing two financial indicators i.e., Gross Return on Investment (GRI) and Financial SelfSufficiency (FSS).

\section{Gross return on investment}

Gross return on investment was calculated for last five years. Standardized gross value of production was calculated by considering wheat as base crop. Net positive worth was calculated to find out the cost of irrigation infrastructure. Standard bank interest rate (12 $\%$ per annum) was used to find out the Net Positive Worth (NPW). From the results, it was found that gross return on investment had highest value of 33 per cent for the year 201314 and was found lowest 10.5 per cent for year 2010-11. The average value of gross return on investment for Bhimsagar Irrigation Project was found to be 21.44 per cent. Table 7 describes gross return on investment. The gross return on investment has continuously increased from 2010-11 to 2013-14 which indicate more area were brought under irrigation.

\section{Financial self-sufficiency}

Financial Self-Sufficiency (FSS) was calculated using operation \& maintenance (O\&M) and Revenue data collected from Irrigation Department, Jhalawar. Eight years data were analyzed and it was observed that there is an increasing trend in the operation and maintenance expenditure. Total revenue collected from irrigation service is Rs. 40 lakh per annum. The table 8 describes O\&M expenditure and revenue collected from 
irrigation so as to asses financial selfsufficiency. The financial self-sufficiency is found on decline trend from value of 174 per cent in year 2006-07 to 54 per cent in 201314. The financial self-sufficiency was equal or more than 100 per cent in years from 2006-07 to 2008-09, indicates less operation and maintenance expenditure incurred than revenue collected. The financial selfsufficiency obtained was less than 100 per cent from years 2009-10 to 2013-14. The average value of financial self-sufficiency of Bhimsagar Irrigation Project was found to be 97 per cent.

The output per unit land cropped (OPLC) in 2009-10 was lower as compared to rest of years. The highest output per unit land cropped was in year 2013-14; there is variation in land cropped area from year to year. The output per unit command area was highest in year 2013-14 and lowest in year 2009-10. Output per unit irrigation supply (OPIS) was highest in year 2010-11 whereas Output per unit water consumed (OPWC) was highest in year 2013-14. The OPIS and OPWC both was found minimum in year 2011-12. The irrigation ratio ranges from 28 to 97 per cent and was highest in year 201314. The canal network of Bhimsagar irrigation system is found sustainable from years 201112 to 2013-14 having sustainability of irrigated area (SIA) value higher than 100 per cent. It was maximum in year 2013-14 having SIA value of 153.90 per cent. Maximum value of area infrastructure ratio (AIR) was in the year 2013-14 having AIR value of 166.92 $\mathrm{Km} / \mathrm{ha}$. This ratio was found comparable to its idle indicator in the years from 2011-12 to 2013-14 after completion of rehabilitation activities. gross return on investment indicates the Gross value of product obtained in the irrigation project command which is influenced based on the average annual rainfall and crop production and its selling rices.. Financial self-sufficiency reveals that operation and maintenance expenditure has been continuously increasing whereas revenue from irrigation services is constant.

\section{References}

Degirmenci, H., Buyukcangaz, H. and Kuscu, H. 2003. Assessment of Irrigation Schemes with Comparative Indicators in the Southeastern Anatolia Project. Turkish Journal of Agriculture and Forestry, 27:293-303.

Kloezen, W.K., Restrego, C. G. and Johnson S. H. 1998. Assessing of Irrigation Performance with Comparative Indicators: the case of the Alto Rio Lerma Irrigation District, Mexico. Colombo, Research Report 22. IWMI, Sri Lanka.

Molden, D., Burton, M. and Bos, M.G. 2007. Performance Assessment, Irrigation Service Delivery and Poverty Reduction: Benefits of Improved System Management. Irrigation and Drainage, 56:307-320.

Molden, D.J., Sakhivadivel, R. Christopher, J.P. Charlotte, F. and Kloezen, W.H. 1998. Indicators for Comparing Performance of Irrigated Agricultural Systems. Colombo. Research Report 20, Sri Lanka: IWMI.

Mukherji, A., Facon, T., de Fraiture, C., Faures, J.M., Fuleki, B., Giordano, M., Molden, D. and Shah, T. 2009. Revitalizing Asia`s Irrigation: to meet tomorrow`s food needs. IWMIPublications. Colombo, Sri Lanka.

Murray-Rust, D.H., and Snellen, W.B. 1993. Irrigation System Performance Assessment and Diagnosis. International Irrigation Management Institute, Colombo. Sri-Lanka. 148

Pareira, L., 2003. Proceeding of the internationalworkshop on participatory management of irrigation systems, 
water utilization techniques hydrology, a session of the 3rd world water forum, Theme: Agriculture, Food \& Water, March 2003.

Phadnis, S.S., and Kulshrestha, M. 2010. Need of Benchmarking For Socially and Environmentally Sustainable Development of a Major Irrigation Scheme. pp: 7.

Sarma, P.B.S., and Rao, V.V. 1996. Evaluation of an Irrigation Water Management Scheme - A Case Study. Agricultural Water Management, 32:81195.

Sener, M., and Albut, S. 2011. Irrigation
Performance Assessment in Turkey: Thrace Region Case Study. Bulgarian Journal of Agricultural Science, 17 (4):521-530.

Sener, M., Yüksel, A.N. and Konukcu, F. 2007. Evaluation of Hayrabolu Irrigation Scheme in Turkey using Comparative Performance Indicators. Journal of Tekirdag Agricultural Faculty. 4(1):27-38

Vermillion, D.L., 2000. Guide to Monitoring and Evaluation of Irrigation Management Transfer. http://www.impim.org/library.html

\section{How to cite this article:}

Jitendra Rajput and Mahesh Kothari. 2017. Performance Appraisal of Bhimsagar Irrigation Scheme using Comparative Performance Indicators. Int.J.Curr.Microbiol.App.Sci. 6(10): 33833393. doi: https://doi.org/10.20546/ijcmas.2017.610.397 